\title{
Disentangling Supply Chain Management Competencies and their Impact on Performance \\ A Knowledge-based View
}

Flöthmann, Christoph; Hoberg, Kai; Gammelgaard, Britta

Document Version

Accepted author manuscript

Published in:

International Journal of Physical Distribution \& Logistics Management

DOI:

10.1108/IJPDLM-02-2017-0120

Publication date:

2018

License

Unspecified

Citation for published version (APA):

Flöthmann, C., Hoberg, K., \& Gammelgaard, B. (2018). Disentangling Supply Chain Management Competencies and their Impact on Performance: A Knowledge-based View. International Journal of Physical Distribution \& Logistics Management, 48(6), 630-655. https://doi.org/10.1108/IJPDLM-02-2017-0120

Link to publication in CBS Research Portal

\section{General rights}

Copyright and moral rights for the publications made accessible in the public portal are retained by the authors and/or other copyright owners and it is a condition of accessing publications that users recognise and abide by the legal requirements associated with these rights.

\section{Take down policy}

If you believe that this document breaches copyright please contact us (research.lib@cbs.dk) providing details, and we will remove access to the work immediately and investigate your claim. 


\title{
Disentangling Supply Chain Management Competencies and their Impact on Performance: A Knowledge-based View
}

\author{
Christoph Flöthmann, Kai Hoberg, and Britta Gammelgaard
}

Journal article (Accepted manuscript*)

\section{Please cite this article as:}

Flöthmann, C., Hoberg, K., \& Gammelgaard, B. (2018). Disentangling Supply Chain Management Competencies and their Impact on Performance: A Knowledge-based View. International Journal of Physical Distribution \& Logistics Management, 48(6), 630-655. https://doi.org/10.1108/IJPDLM-02-2017-0120

\section{DOI: 10.1108/IJPDLM-02-2017-0120}

This article is [ E Emerald Group Publishing and permission has been granted for this version to appear here: https://research.cbs.dk/en/publications/disentangling-supply-chain-management-competencies-and-theirimpa.

Emerald does not grant permission for this article to be further copied/distributed or hosted elsewhere without the express permission from Emerald Group Publishing Limited.

* This version of the article has been accepted for publication and undergone full peer review but has not been through the copyediting, typesetting, pagination and proofreading process, which may lead to differences between this version and the publisher's final version AKA Version of Record. 


\title{
Disentangling supply chain management competencies and their impact on performance: a knowledge-based view
}

- Authors' names blinded for peer review -

\begin{abstract}
Purpose - This paper seeks to extend the understanding of supply chain management (SCM) competencies by splitting them into individual and organizational components and measuring their impact on SCM performance.

Design/methodology/approach - Hypothesized relationships are tested using structural equation modeling and bootstrapping mediation analysis based on a multi-national survey with 273 managers while drawing on theory of knowledge management and literature streams of individual supply chain competencies in the fields of SCM and HRM, respectively.

Findings - The analysis reveals that individual SCM competencies and organizational SCM knowledge positively influence SCM performance to a similar magnitude. Moreover, organizational learning enhances individual competencies and organizational knowledge significantly and equally while corporate training programs fall surprisingly short of expectations. The disentanglement of SCM competencies renders HRM's contribution to SCM visible by revealing the impact of HRM and learning practices on competencies, knowledge, and performance.

Research limitations/implications - To validate the findings, future research could apply different research methods such as case studies and focus on more countries to reduce potential methodological and regional biases.

Practical implications - The results suggest that corporate training programs need further development. Organizational learning's strong direct and indirect effects have two main implications: First, it should serve as motivation for organizations to constantly improve their learning capabilities. Second, these only tap its true potential for enhancing SCM performance if they first elevate individual competencies and organizational knowledge.

Originality/value - This is the first paper to distinguish between individual competencies and organizational knowledge on finely nuanced levels. While the organizational knowledge level effect on performance has been studied before, this paper extends this effect to also hold true for the individual level.
\end{abstract}

Keywords: Supply chain management competencies, Organizational knowledge, Organizational learning, Training, Skills

Paper type: Research paper 


\section{INTRODUCTION}

It is widely accepted that a company's supply chain management (SCM) capabilities have a positive impact on its performance by decreasing costs, reducing inventory write-offs and increasing revenues (Ellinger et al., 2011; Wagner et al., 2012). Recent SCM research has used a knowledge-based view (KBV) - that considers knowledge as the strategically most important resource of a firm (Grant, 1996) - to investigate the impact of knowledge on supply chain and company performance (Hult et al., 2004; Craighead et al., 2009). These types of studies have frequently focused on the impact of organizational knowledge rather than on the competencies of individuals. Both components are often aggregated into one concept (Hult et al., 2006). However, classical knowledge management research distinguishes between the two dimensions (Felin and Hesterly, 2007).

The oversimplification of knowledge and competencies in the recent SCM literature is problematic because it fails to capture the true locus of the knowledge involved in value creation (Felin and Hesterly, 2007). There is an ongoing debate about the extent to which value is created. Within this divergence among knowledge management scholars, the majority hold the view that company-level knowledge is the locus of value creation (e.g., Kogut and Zander, 1992; Eisenhardt and Martin, 2000). Advocates of competencies at the individual level are in the minority (e.g., Simon, 1991; Grant, 1996). However, the fact that the debate among researchers is still ongoing suggests that it is worthwhile to investigate the separate contribution of individual competencies and organizational knowledge. This topic has not yet been specifically investigated in SCM. Thus far, only Schoenherr et al. (2014) have studied knowledge management on a more finely nuanced level by distinguishing between tacit (intangible) and explicit (tangible) knowledge in supply chains. These authors found that due to its more imperfect mobility, tacit knowledge contributes 
more towards achieving competitive advantage. However, their objective was not to distinguish between individual SCM competencies and organizational SCM knowledge, which is the purpose of this paper.

Organizational knowledge is defined as "knowledge beyond the aggregation of individual knowledge" (Nahapiet and Ghoshal, 1998). Other researchers have conceptualized organizational knowledge as the knowledge stored in databases, routines, processes, documentations, manuals and machines (Felin and Hesterly, 2007). In general, organizational knowledge is easily codified and shared with others at practically zero marginal cost. There is a certain overlap with the principle of "explicit" knowledge found in the KBV. Explicit knowledge can be readily articulated, codified, accessed and verbalized (Hélie and Sun, 2010). However, organizational knowledge can also incorporate elements of tacit knowledge (i.e., knowledge that is intangible and difficult to transfer verbally or written such as the Toyota quality culture (Nonaka, 1991) or Amazon's company mindset for innovative supply chain solutions).

On the other hand, individual competencies comprise the knowledge, skills and abilities of personnel that are related to on-the-job performance (Mirabile, 1997). Traditionally, individual competencies and their development have been a key sub-domain of human resource management (HRM) research. There is theoretical and empirical evidence that employee competencies and development affect a company’s SCM performance (McAfee et al., 2002). However, academic research has rarely addressed the link between HRM and SCM (Hohenstein et al., 2014). Similarly, practitioners have largely neglected HRM and its impact on SCM (Sweeney, 2013), although an improved understanding of SCM personnel and their traits is critical to supporting important HRM-related activities such as recruitment, succession planning, training and development (John, 2015). 
The overarching premise of this research is to shed more light on the relationship between SCM and HRM and how HRM can positively influence a company's SCM performance through knowledge and employee development. Accordingly, the first objective of this paper is to extend the understanding of SCM competencies on a more granular level by splitting SCM knowledge into its individual and organizational knowledge components. The second objective of this study is to uncover the antecedents and the impact of the different knowledge components on SCM performance by developing a comprehensive model of value creation through SCM competencies. These two objectives are approached as follows: The paper first investigates and quantifies the individual SCM competencies and organizational SCM knowledge as focal constructs to SCM performance. Next, it analyzes the impact of organizational learning and corporate training as the antecedents of individual competencies and organizational knowledge.

The hypotheses are tested using structural equation modeling (SEM) with a maximum likelihood (ML) estimation on the basis of survey data collected from 273 supply chain professionals from companies based in Europe.

The remainder of the paper is structured as follows: The next section presents the theoretical basis and development of the hypotheses. We then outline the research design and the methodological approach. Afterwards, we summarize the results of our analysis. Next, we discuss the findings and the final section summarizes the theoretical and managerial implications and concludes.

\section{THEORETICAL BASIS AND HYPOTHESES}

The KBV is chosen as the theoretical basis to link SCM and HRM research on competencies. Based on this view, we developed a set of nine hypotheses that together build a model that can be 
used to better understand the impact of organizational and individual competencies, respectively, on SCM performance.

\section{The role of HRM, knowledge and learning concepts in the context of SCM}

Numerous studies in the management literature have demonstrated a positive impact of HRM on a variety of performance outcomes (e.g., Huselid, 1995). The compelling logic of KBV conceptualizes the motivation for employing and developing highly competent personnel. Drawing on the KBV's foundation in the resource-based view, capable individuals can establish a competitive advantage if their competencies are valuable, rare, inimitable and non-substitutable (i.e., the VRIN criteria) (Wernerfelt, 1984; Barney, 1991; Grant, 1996).

For example, Aguinis and Kraiger (2009, p. 459) show that training enhances recipients' declarative, procedural and strategic knowledge. These authors found organizational performance benefits such as "profitability, effectiveness, productivity and operating revenue per employee." These findings are expected to hold true in the discipline of SCM but require closer observation due to the unique characteristics of SCM. Unlike other traditional management disciplines like sales or marketing, SCM is a relatively new management concept that stands out due to its holistic, global and intercultural orientation (Cottrill, 2010).

One of HRM's primary goals is to develop employee competencies by designing and implementing adequate training and continuing education programs that facilitate change on individual and organizational levels (Vidal-Salazar et al., 2012). In accordance with KBV, Lawler (1994, p. 7) proposed that "there is a need for the development of skill sets that are appropriate and unique to the organization and that will provide core competencies and competitive advantage." Training allows companies to align employee competencies with the competencies that their strategies require and deploy personnel flexibly in an environment of changing activities. 
Moreover, employees can only contribute critical capabilities to their teams if their employer has developed the employees' individual skills (Lawler, 1994). Several studies have reported that HRM activities, including training, have a positive effect on a variety of SCM performance dimensions, particularly quality metrics (Jayaram et al., 1999; Ahmad and Schroeder, 2003). Competency development is essential for many management roles, but it is especially vital for SCM, a truly cross-functional profession (Flöthmann and Hoberg, 2017). Gowen and Tallon (2003) emphasize that strengthening problem-solving skills and the ability to work in teams through training is significantly related to later supply chain success. Based on the above findings, we propose the following hypothesis:

H1. Corporate training is positively related to individual SCM competencies.

The literature indicates that learning capability is an important factor in company success (Leonard-Barton, 1992; DiBella et al., 1996). A corporate learning culture/atmosphere facilitated by the top management and HRM practices is often the seedbed of organizational learning capability. Hult et al. (2003) discussed the potential role of organizational learning as a strategic resource in supply chains. These authors found that organizational learning has a positive and direct effect on a set of learning, supply management, management and performance consequences. The arguments noted above can be extended to individual SCM competencies. This notion is supported by general management research: Flores et al., 2010 (p. 645) found that "information becomes knowledge when it is processed by the actor." Hence, individuals assimilate information and then relate it to their previous knowledge and skills to convert it into new facets of their competencies. Spekman et al. (2002) showed, in one of the very few SCM-focused studies on the relationship between learning and competencies, that a learning environment can improve the abilities of SCM's individual members. Therefore, our next hypothesis is: 
H2. Organizational learning is positively related to individual SCM competencies.

According to Flores et al. (2010), organizational learning is related to information management. The flow of information is a central element in supply chains: information must be acquired, integrated and distributed internally and across company boundaries. Organizational entities communicate and make crucial decisions (e.g., such as determining order quantities and production schedules) by exchanging information. Various researchers have agreed that information is the basic input for organizational knowledge (Kogut and Zander, 1992; Davenport and Prusak, 1998). In fact, knowledge can be regarded as "the processing of ready-made information" (Nass, 1994, p. 39). Based on the management literature, we assume that organizational learning must first be linked to organizational knowledge and then converted into performance. Common sense dictates that information and knowledge are quite similar, and therefore it is necessary to define the distinction and the connection between information and knowledge. According to Nonaka (1991), p. 16), “information is a necessary medium for formalizing knowledge." The organizational sub-processes of learning can be regarded as a predecessor to organizational knowledge because shared information lays the foundation for developing into knowledge. Accordingly, the following hypothesis is proposed:

H3. Organizational learning is positively related to organizational SCM knowledge.

Previous studies have shown that organizational knowledge can be a strategic resource in SCM. Hult et al. (2006) investigated why some supply chains perform better than others. These authors found that the degree to which strategy and organizational knowledge elements mesh has a direct impact on supply chain performance. Previously, Hult et al. (2004) investigated the impact of knowledge management on cycle time in strategic supply chains and found that the knowledge development process can explain substantial variance. Hult et al. (2007) count knowledge 
development among the levers for improving strategic SCM. Overall, the authors concur that knowledge is a valuable, rare, inimitable, and non-substitutable resource in SCM, leading to a competitive advantage. Recently, Schoenherr et al. (2014) showed empirically that knowledge has multidimensional, positive effects on supply chain performance. We also assume a positive relationship between organizational SCM knowledge and SCM performance but do so by considering individual SCM competencies and antecedent factors. Therefore, we propose the following hypothesis:

H4. Organizational SCM knowledge is positively related to SCM performance.

Generally, previous research in the SCM domain centered around the notion that SCM processes are human-centric (Myers et al., 2004) and consequently that employing individuals with strong SCM competencies should translate into both improved employee and organizational performance (Derwik and Hellström, 2017). The human-centricity and the impact on multiple performance metrics make qualified supply chain managers valuable according to the KBV.

Furthermore, there is widespread agreement among researchers and managers that we are facing an acute shortage of qualified supply chain personnel (John, 2015). Such a shortage, coupled with research and anecdotal references that have consistently suggested that supply chain managers need to possess unique competencies that differentiate them from other managerial staff, make qualified supply chain managers also rare. In addition, the fact that SCM has evolved towards a more strategic role suggests that employees who adapt to rapid development have made themselves also highly inimitable (Slone et al., 2007). Since intangible abilities such as adaptability are difficult to train and develop, competitors can be expected to struggle as they seek to replicate highly qualified staff. Despite recent technological advancements and automation in supply chains, qualified SCM staff are even non-substitutable. In fact, advancements have made 
qualified staff even more essential because employees need sophisticated levels of education to manage high tech systems that affect the ultimate performance of the supply chain directly. In sum, SCM personnel, measured by their multi-dimensional, individual SCM competencies, can be expected to fulfill the VRIN criteria and contribute to sustained superior performance. Accordingly, our fifth hypothesis is:

H5. Individual SCM competencies are positively related to SCM performance.

\section{Indirect effects of organizational learning and corporate training on SCM performance}

Malhotra et al. (2014) reported that mediation analysis is a useful technique for deriving more robust and more insightful conclusions from empirical research that go beyond direct statistical relationships. Mediation analysis can build and test theories on deeper levels, especially by focusing on indirect effects between the modeled factors. We are particularly interested in the indirect effects of organizational learning and corporate training on SCM performance. Previous studies have shown that organizational learning is directly associated with various managerial performance measures. However, to the best of our knowledge, none of these studies have further explored the existence and impact of indirect effects of training and organizational learning on SCM performance. Studying indirect effects are of particular importance because their presence suggests that training and organizational learning have to be transformed to competencies or knowledge first (mediation) in order to improve SCM performance.

Hult (1998) and Hult et al. (2003) showed that organizational learning can be a strategic resource because it positively affects multiple aspects of supply management (e.g., the organization's cycle time and overall performance). However, these studies did not incorporate potential mediators between organizational learning and performance measures. Hult (1998) investigated the effect of organizational learning on purchasing information processing and the subsequent effect on 
subjective and objective cycle time. Although information processing is a mediator, Hult (1998) did not analyze the indirect effects of organizational learning on cycle time. Tippins and Sohi (2003) showed that organizational learning acts as a mediator between IT competency and company performance. Therefore, the hypothesized and analyzed relationships between organizational learning and performance measures are also direct (with antecedent factors).

The lack of attention paid to organizational learning as a mediating factor with indirect effects on performance is surprising. The next section shows that organizational learning is an essential precondition for knowledge and competencies which in turn have been empirically linked to performance measures. Consequently, organizational learning can be expected to affect SCM performance indirectly (i.e., it is mediated by individual competencies and organizational knowledge components that are modeled as focal constructs). Therefore, we propose our next hypotheses:

H6a. The relationship between organizational learning and SCM performance is mediated by individual SCM competencies.

$H 6 b$. The relationship between organizational learning and SCM performance is mediated by organizational SCM knowledge.

Consistent with previous arguments, we can also expect corporate training to have indirect effects on SCM performance. Most HRM studies that have focused on training have suggested a positive effect on competency and capability development. Furthermore, Aguinis and Kraiger (2009) showed that training enhances observable organizational performance measures such as profitability, productivity, and operating revenue per employee. We certainly expect the direct effects of corporate training on competency levels to account for most of the total effect of training 
on SCM performance. Corporate training programs are designed to develop human resources and competencies in the first place. With a lag in time, some of the competencies are translated into actual performance. Therefore, based on previous arguments, we propose the next hypothesis:

H7. The relationship between corporate training and SCM performance is mediated by individual SCM competencies.

However, studies have suggested that current training programs still lack the sufficiency and efficiency required for developing the performance-related competencies of supply chain managers in a desirable fashion (e.g., Ellinger and Ellinger, 2014). Consistent with this observation, Ellinger et al. (2008) found a significant positive contribution of formal training to employee-level performance indicators. However, formal training falls short of affecting the organization's bottom-line performance of logistics service providers. This finding remains only partially surprising if it is considered in light of company investments in SCM training. In a recent study, Gibson et al. (2013) determined that SCM professionals only receive limited training in terms of hours and monetary investments in their education. In conclusion, the potential indirect effects of training initiatives on SCM performance are likely to be limited. In contrast, organizational learning has been strongly and directly linked to various SCM-related performance measures, and such learning is also an enabler that creates knowledge in the first place (Hult et al., 2000; Hult et al., 2003). We therefore expect the positive contributions of organizational learning to be translated into actual performance mediated by individual SCM competencies and organizational knowledge. We expect organizational learning's indirect effect to be stronger than corporate training because previous studies have observed a strong link between organizational learning and performance-often stronger than the one between training and development activities. This situation leads to our last hypothesis: 
H8: The indirect effects of organizational learning on SCM performance are stronger than the indirect effects of corporate training.

Exploring the magnitudes of effect sizes is important for deriving implications for practice. On the one hand, the findings can help companies to prioritize future measures for improving SCM performance. For instance, if one capability is found to be much more influential in terms of performance, then firms should develop that respective capability before others. On the other hand, the magnitudes of effect sizes also indicate which component possesses more potential for improvement. For example, if the indirect effect of corporate training on SCM performance is rather limited, then firms should realize that they have to re-design and optimize their development programs.

Figure 1 provides an overview of the conceptual model with all of the hypothesized relationships stated and described before. The full model consists of three building blocks. First, corporate training and organizational learning are conceptualized as antecedents that link to our focal constructs in $\mathrm{H} 1, \mathrm{H} 2$ and $\mathrm{H} 3$.

Second, H4 and H5 link our focal constructs (organizational SCM knowledge and individual SCM competencies) to SCM performance. Their disentanglement is the premise of this paper. Finally, indirect relationships are modeled $(\mathrm{H} 6 \mathrm{a} / \mathrm{b}, \mathrm{H} 7, \mathrm{H} 8)$ to explore the mediated effects of the antecedents on SCM performance to derive more insightful conclusions beyond a direct statistical relationship. 


\section{RESEARCH DESIGN AND METHODOLOGY}

\section{Questionnaire development and pre-testing}

All of our constructs are latent variables that can be measured indirectly. To test our hypothesized model, we followed a two-step approach, as suggested by Gerbing and Anderson (1988). We first developed a measurement model (a confirmatory factor analysis (CFA)) and then tested the relationships between constructs using a structural path model. To ensure the reliability and validity of the measurements, we investigated the management literature for previously employed multi-item measurement scales. The complete questionnaire with references is included as Appendix B. Three subsequent waves of pre-testing with 18 people of various backgrounds-i.e., supply chain executives, a random sub-sample of supply chain managers, and fellow researchers with methodological and functional expertise - resulted in a sound and thorough questionnaire.

\section{Measurement instruments}

We carefully selected all of the measures that we used by adopting or adapting them from previous papers after a rigorous literature review that identified the following scales as being a best fit for the study's purposes.

Corporate Training: We adapted items of Ahmad and Schroeder (2003) and Ahire et al. (1996) to measure the corporate training efforts of companies. These items were used in a comparable research setting to measure training effort of companies in SCM context, which ensures a good fit to our study. They are related to budget and resource allocation for training programs and HRM support for employee training, essential prerequisites for successful training initiatives (McKinnon et al., 2017). 
Organizational Learning: Measurements used by Flores et al. (2010) were adapted to design the second-order construct for organizational learning. The five first-order constructs of these authors constitute a common body of knowledge and understanding regarding organizations' learning subprocesses that are concerned with information, an essential component of SCM (Lee et al., 1997). We focused on and employed three of the five initial first-order constructs for the following reasons. The three focus-constructs are information acquisition, information distribution and information absorption. We omitted the construct organizational memory because this sub-process is too closely related to organizational knowledge. Memory is the last step of information processing before it becomes knowledge (Flores et al., 2010). The closeness of memory to knowledge might puzzle respondents and add methodological issues with indicators loading on both second-order constructs. The second dimension of Flores et al. (2010) that we decided to omit is information interpretation. Because interpretation is typically a subjective matter on an individual level, closely related to someone's abilities and knowledge, this factor could be confused with the individual competencies construct. Moreover, the three remaining constructs still cover the majority of facets.

Individual SCM Competencies: This construct was based on the seminal work of Gammelgaard and Larson (2001). These authors identified three categories of relevant skills/knowledge of supply chain and logistics managers that are widely accepted now. Based on an exploratory factor analysis, 45 competencies could be classified into three categories: managerial, SCM core and IT competencies. This situation suggests that SCM competencies are indeed multi-dimensional and require measurement by a second-order construct. The phrasing and logic of the items used to measure those factors were adopted from Byrd and Turner (2001). 
Organizational SCM Knowledge: To measure organizational SCM knowledge, we adopted the construct of Hult et al. (2006) but made some adjustments. In their paper, Hult et al. (2006) measured "knowledge" with seven first-order constructs, each measured with at least three items. After careful consideration, we dropped four of those seven first-order constructs because-in foresight - their inherent items were too similar to items included in the individual SCM competencies measures. Those items might have accordingly caused interfering cross-loadings. To prevent this situation, we selected the three key knowledge constructs that described organizational knowledge most precisely and accurately. This decision was necessary because one of the primary goals of this paper is to clearly distinguish between organizational and individual knowledge components. Because we still employ 12 items to measure the three remaining subconstructs - accessibility of knowledge, knowledge intensity and knowledge use-we are confident of the accuracy of this construct.

SCM Performance: The literature provides many different constructs to measure SCM performance. In this study, we used a combination of items used previously by Rexhausen et al. (2012) and Fawcett and Waller (2013). We use six measurement items, which compare the focal firm's performance with the best competitors in terms of supply chain cost, quality, responsiveness, innovation, improvement and overall performance. By employing six measures, we ensure broad measurement of this important endogenous factor and try to capture the different facets of SCM considered to be the most important (Fawcett and Waller, 2013).

\section{Control variables}

To avoid omitting variables that may influence and confound the relationships of the key variables in our model, we introduced three control variables (binary coded) to the structural model. First, we eliminated country effects by controlling for the country of the respondent's workplace. 
Economic, political and cultural differences influence the strategic and operational options of firms and therefore might influence performance (e.g., Bozarth et al., 2009). Second, firm size might be related to performance and internal practices. On the one hand, smaller firms might have fewer financial and managerial resources for implementing sophisticated SCM and HRM practices than larger firms (e.g., Cao and Zhang, 2011). On the other hand, smaller firms might be more innovative and efficient at executing such practices. Therefore, to eliminate these potential confounds, we followed the recommendation to control for firm size (e.g., Terjesen et al., 2011) using number of employees. Lastly, we controlled for the industry affiliation (based on the industry classification benchmark) that could also have an impact on SCM performance. Different industries are typically subject to different SCM maturity levels due to the degree of impact on overall company performance (Eroglu and Hofer, 2011).

\section{Data sample and collection procedure}

To examine our hypotheses, we used databases from the Copenhagen Business School and the Kühne Logistics University containing the contact details of SCM and SCM-related managers. A link to an online survey was sent to potential respondents via e-mail between the end of January and March 2015. As an incentive to participate, we promised to support a charity organization for every questionnaire that was completed. Excluding outdated or incorrect e-mail addresses, we contacted 1,465 potential respondents and received 337 completed questionnaires.

The first item of the questionnaire was a screening question intended to identify knowledgeable respondents and, therefore, reliable data quality (Fowler, 2014). We asked the respondents to identify their level of agreement with the statement, "I am knowledgeable about my firm's SCM, e.g., about their activities and responsibilities in the organization, overall performance indicators, and employee training programs in place." on a 5-point Likert scale. Only respondents who 
"agreed" (4) or "strongly agreed" (5) with that statement qualified for our study. Consequently, 64 participants (strongly) disagreeing (1/2) or who were not sure (3) were eliminated because their knowledge of our research topics and fit to our study were questionable. This elimination step left 273 reliable responses in our final sample. These numbers translate to an effective response rate of $18.8 \%$, which is consistent with comparable studies (e.g., van der Vaart and van Donk, 2008). Table 1 lists the descriptive statistics of our sample. The majority of respondents (76.2\%) came from German-speaking countries (Germany, Austria and Switzerland) followed by Denmark $(18.3 \%)$. The largest share of respondents in terms of company hierarchy came from the middle (42.5\%) and lower (23.4\%) management levels. These people usually have a good overview of their company's internal SCM and HRM activities and possess reasonable levels of business experience to serve as reliable sources.

\section{Response and common method bias}

To account for potential response bias, the means of all responses of the earliest 30 respondents and latest 30 respondents were compared using a two-tailed $t$-test (Lambert and Harrington, 1990; Wagner and Kemmerling, 2010). We found no statistically significant differences $(\mathrm{p}<0.05)$. A $t$ test comparison of two descriptive variables (company revenues and number of employees) of the 30 earliest and latest respondents did not furthermore reveal any statistically significant difference. We concluded that response bias is not a serious concern in this dataset. -Insert Table 1 Approximately Here-

This study is a single informant survey that measures independent and dependent variables simultaneously. Consequently, our analysis might be affected by common method bias (CMB) (Guide Jr. and Ketokivi, 2015). Following two remedy techniques proposed by Podsakoff et al. (2003), we applied two statistical techniques to assess the potential threat of CMB: (i) a priori by 
installing a marker variable in the questionnaire, and (ii) ex post by installing a common latent factor in our measurement model. Neither of the two techniques indicated an interfering presence of $\mathrm{CMB}$ in our data, giving us confidence to proceed with our analysis.

\section{The measurement model}

Estimation method: In our main analysis, we used IBM Amos 22 covariance-based software and ML estimation. Maximum likelihood estimation has been deemed to be the best-fitting choice for theory-testing research settings such as ours (Kline, 2011).

Convergent validity and reliability: We used CFA to test the reliability and validity of our constructs. All measured constructs yielded high Cronbach's alpha values (average $=0.842$, $[0.746 ; 0.901])$ and composite reliability $(\mathrm{CR}$, average $=0.851,[0.768 ; 0.905])$, exceeding the recommended thresholds (Cronbach, 1951; Hair et al., 2010). Both measures indicated construct reliability. Convergent validity was also positive. The standardized factor loadings were all greater than $0.5[0.542 ; 0.932]$ with an average of 0.783 , and all of the loadings were statistically highly significant at $\mathrm{p}<0.001$ (Vickery et al., 2003; Dröge et al., 2004). Two additional heuristics-based approaches also indicated convergent validity. All estimates were at least twice as large as their standard errors (Anderson and Gerbing, 1988), and the average variance extracted (AVE) was above 0.5 for all constructs (Fornell and Larcker, 1981). A summary of convergent validity and reliability measures is listed in Table 2. Summary data on the item level are listed in Appendix A.

Discriminant Validity: To evaluate discriminant validity, we used the inferential $\chi^{2}$-difference test complemented by a heuristic assessment. The p-values of the 10 possible constrained models versus the unconstrained models had to be below 0.005 to achieve a $5 \%$ significance level (Voorhees et al., 2016). Of the 10 possible inferential $\chi^{2}$-difference tests, the unconstrained model passed seven times and failed the test marginally twice $(\mathrm{p}=0.022$ and 0.035$)$ and significantly 
once $(p=0.176)$. Unfavorable correlations existed between corporate training and the secondorder-construct individual SCM competencies. However, a theoretical content-based evaluation of the respective responses should rule out a problematic statistical overlap. The items address very different topics and should therefore not measure the same latent variables accidentally. To further test discriminant validity, we calculated the $95 \%$ confidence intervals (CIs) of the inter-construct correlations. Since no $95 \%$ CI included a correlation of 1.0, our model demonstrated discriminant validity (Anderson and Gerbing, 1988). The heuristics-based approaches of Fornell and Larcker (1981) pointed in the same direction in each case. The discriminant validity measures are listed in Table 3.

Multicollinearity: We tested for the potential multicollinearity of factors that share a common dependent factor in the structural model as a robustness check. The two highest measured variance inflation factors (VIF) values were 4.6 and 3.6. All other VIFs were less than 3.0. On the whole, these VIF values are rather low (Hair et al., 2010). The combination of low VIFs, mediocre-tohigh dependent latent construct $\mathrm{R}^{2}$ values, high average measurement reliability for the respective constructs and low standard errors of estimates indicates that multicollinearity is not a concern in our analysis.

Model Fit: Our strategy to assess model fit used a mix of global and incremental model fit indices, i.e., model $\chi^{2}$ with an adjusted p-value determined by Bollen-Stine (1990) bootstrapping and the technique of Fornell and Larcker (1981) to assess the model fit from multiple perspectives. The model $\chi^{2}$ was $=1109.630, \mathrm{df}=615$. In sum, the assessments indicate that our measurement model yields a good fit, which means that our model corresponds well to the data: CFI $=0.943$, IFI $=$ $0.943, \mathrm{TLI}=0.937, \mathrm{RMSEA}=0.047$ with P-CLOSE $=0.840(\mathrm{Hu}$ and Bentler, 1999; Kline, 2011; Bollen, 1989). 
Insert Table 2 Approximately Here-

-Insert Table 3 Approximately Here-

\section{RESULTS}

The structural model: direct effects

We used SEM to test our hypotheses regarding the relationships between our constructs. The structural model yielded an acceptable fit: $\mathrm{CFI}=0.921, \mathrm{IFI}=0.922, \mathrm{TLI}=0.915, \mathrm{RMSEA}=0.054$ with PCLOSE $=0.080(\mathrm{Hu}$ and Bentler, 1999; Iacobucci, 2010; Kline, 2011). The hypothesis results are listed in Table 4 and shown in Figure 2. None of the control variables had a statistically significant effect on any of the endogenous constructs. However, we retained them in the model for completeness. Therefore, H2, H3, H4 and H5 are all fully supported. The unstandardized regression weights are statistically significant at the $\mathrm{p}<0.001$ level. H1 is only partially supported. Although the effect is statistically significant at the $p<0.01$ level, the standardized regression weight (SRW) is very low (0.182), particularly in relation to organizational learning's effect on individual competencies (H2). According to Chin (1998), a low SRW $(<0.2)$ is insubstantial and of low theoretical value. Given that overall company spending on corporate training worldwide was $\$ 130$ billion in 2013 (Forbes, 2015), its weak effect is particularly surprising. Our findings suggest that the corporate SCM training programs in place today are ineffective. In contrast, the results show that organizational learning is positively and strongly associated with both competencies $(\mathrm{SRW}=0.766)$ and organizational knowledge $(\mathrm{SRW}=0.802)$. This fact means that information acquisition, distribution and absorption are crucial antecedents that facilitate high competency and organizational knowledge levels. 
Competencies $(\mathrm{SRW}=0.315)$ and organizational knowledge $(\mathrm{SRW}=0.430)$ positively influence SCM performance. More importantly, they do so at similar magnitudes.

\section{Indirect effects}

We next subjected the mediating role of focal constructs within the model to closer scrutiny. Competencies and organizational knowledge mediate between corporate training, organizational learning and SCM performance. Previous studies have demonstrated the direct and positive effect of organizational learning on SCM and supply chain performance (Hult, 1998; Hult et al., 2003). Furthermore, because organizational learning is related to information management, other studies have found empirical evidence that information absorption (Devaraj et al., 2007), processing (Hult et al., 2004) and sharing (Lee et al., 1997) have positive effects on supply chains. We shed further light on the indirect effects using mediation analysis. We also investigated the indirect effect of corporate training on SCM performance, and expected that this effect would be smaller than the indirect effects of organizational learning (H8). To test the mediated effects, we applied the highly regarded bias-corrected bootstrapping approach (Malhotra et al., 2014). The results are listed in Table 5. The indirect effect of corporate training on SCM performance is almost negligible (SRW $=0.057)$. Therefore, $\mathrm{H} 7$ is only partially supported. Organizational learning's indirect effect is relatively high $(\mathrm{SRW}=0.586)$ and highly significant, which fully supports H6a and H6b. H8 is also supported because the mediated effect of organizational learning is considerably larger than that of corporate training. Moreover, mediation is almost evenly split between individual competencies and organizational knowledge. 
The magnitude of the indirect effect of organizational learning on SCM performance through individual and organizational dimensions is further evidence that having information per se is only of partial value. Individuals must process and integrate such information into their organization as databases, manuals and procedures. Organizational learning can reveal its full potential and contribute to SCM performance only if it is transformed into knowledge and competencies.

\section{DISCUSSION AND CONTEXTUALIZATION}

This section aims to relate our empirical findings back to the literature and discuss them in a contextualized manner. Our empirical results statistically support our hypotheses and confirm the idea of disentanglement of SCM competencies. However, the widely varying magnitude of the effects of training and organizational learning is surprising and requires further investigation.

Based on our empirical results, the positive effect of corporate training on individual SCM competences is surprisingly limited (H1). This finding contradicts our expectations from the literature review (Gowen and Tallon, 2003; Ahmad and Schroeder, 2003; Jayaram et al., 1999) and deserves further discussion. To the best of our knowledge, no study has yet investigated the corporate SCM training of European companies in detail. However, the Council of Supply Chain Management Professionals (CSCMP) studied SCM talent development practices of American companies and uncovered potential explanations for the shortfall in training (Gibson et al., 2013) that should be transferable to European companies as well. Our findings support many of the authors' conclusions. First, Gibson et al. (2013) highlight that the most popular current training methods are hands on: $76.2 \%$ of companies use "on-the-job functional training," but only approximately one-third work with certification from universities and professional organizations. That notion was recently supported by similar findings by McKinnon et al. (2017). These authors investigated logistics competencies and training on a global scale. The CSCMP study also showed 
that budget and time allocation for corporate training appears to be one source of poor training performance. The median budget for SCM executive training is $\$ 3,405$ and averages 37.8 hours per year; the corresponding figures are $\$ 1,000$ and 30.4 hours per year for entry-level employees. This training gap persists despite the fact that new hires are heavily involved in operations using high-end IT systems and SCM concepts. Consequently, they are more likely to require more frequent in-depth training. Although some leading organizations have realized the importance of SCM training, most organizations still do not invest in training programs (Gibson et al., 2013).

The strong influence of organizational learning on individual competencies (H2) and organizational knowledge $(\mathrm{H} 3)$ provides empirical evidence for the hypothesized positive impact of companies' information management. In their comprehensive paper used to develop our measurement instruments for organizational learning, Flores et al. (2010) provide interesting suggestions about the key prerequisites for organizational learning practices. They identify participative decision-making, organizational openness, learning orientation and transformational leadership as crucial improvement levers for one or more sub-processes. For example, if organizations promote a high level of participative decision-making among their employees, then employees are more likely to feel free to speak their minds and share experiences (Hult et al., 2000). This corresponds to a positive effect on information absorption (Flores et al., 2010). Accordingly, companies that emphasize organizational openness typically provide an environment of information access and open communication that accepts debate and conflicts as a problemsolving approach while emphasizing information distribution and absorption.

One of our goals was to split the broad term "SCM competencies" into more easily digestible components. Accordingly, we split "knowledge" as used in the literature into its individual and organizational facets to explore their separate contributions to SCM performance (H4 and H5). 
We found that both dimensions contribute similarly to various SCM performance indicators. This finding contradicts knowledge management research that has found evidence in studies across management domains for the hypothesis that organizational knowledge is more valuable than individual knowledge (Kogut and Zander, 1992; Eisenhardt and Martin, 2000). Our results suggest that SCM is indeed special among management domains and that SCM personnel deserve special attention. Based on their personal experience and knowledge, supply chain personnel need to interpret information to ensure that they can make informed decisions. This fact is particularly true in situations in which only a limited number of standardized processes exist. For example, during the implementation of new SCM processes (e.g., new product launches), the responsible employees' contribution is highly important: SCM tools need to be developed from scratch and employees need to understand uncertainties such as unclear customer demand and the sudden appearance of supply glitches. These uncertainties force SCM personnel to be alert and react swiftly to upcoming issues. Once a process is in place and more streamlined, human capabilities are free to become involved in new activities.

However, many SCM activities and responsibilities rely and depend on organizational knowledge because they are process driven. Supply chain management is charged with coordinating end-toend physical, informational and financial flows inside a company and across boundaries with customers and suppliers (Cooper et al., 1997). Although SCM personnel must possess a comprehensive set of competencies, processes can be standardized. In particular, major companies with large production facilities, high capital investments in IT and infrastructure, high SCM maturity levels and products in the later stage of the product life cycle can standardize and automate their supply chain activities. Therefore, SCM knowledge is mainly organizational. 
The mediation analysis provides empirical evidence for the hypothesized indirect contribution of organizational learning to SCM performance $(\mathrm{H} 6 \mathrm{a} / \mathrm{b})$. These indirect effects are also found to be a much stronger driver of SCM performance than corporate training (H8). The managerial implications point to diverging directions. First, it suggests that companies with limited resources and capacities should focus on facilitating a fruitful organizational learning environment first before they consider fully re-designing their SCM training programs. On the other hand, if companies already possess strong organizational learning capabilities, advancing their SCM training initiatives might leave more room for developing the SCM competencies of the personnel.

Our findings extend previous research that studied organizational learning's direct link to performance metrics. In particular, we add two new layers to the findings of Hult et al. (2003) that organizational learning can constitute a strategic resource in supply chains. First, Hult et al. (2003) found that organizational learning has positive direct effects on a set of learning, supply, management and performance outcomes. We find a positive effect on different SCM performance metrics, extending the list of positive facets incorporated in organizational learning. Second, and even more interestingly, we find such strong effects even in indirect relationships. In particular, these findings suggest that organizational learning fully reveals its potential by supporting the creation of organizational knowledge and upskilling of individual competencies. The finding that organizational learning constitutes not only an important direct driver but also a mediator for performance confirms its strategic role in supply chains. 


\section{CONCLUSION}

\section{Contributions to the literature}

The theoretical contributions of this study are manifold. Most importantly, it takes a multidisciplinary approach to integrating HRM concepts into the SCM literature, responding to recent calls stressing the need for more HRM-related research in the context of SCM (Fisher et al., 2010). This request was fueled recently by studies that indicated a severe global shortage of qualified talent (John, 2015). The problem hereby is two-fold: First, existing personnel often lack the competencies required for the job. Hence, their competencies need to be developed which increases the importance of HRM activities in SCM. Secondly, there are simply too few people to fill newly created SCM jobs. Hence, this scarce resource — talented personnel—must be used most effectively and efficiently. In sum, we must understand multiple aspects of HRM such as competencies, knowledge, learning and training better to determine appropriate counter measures for the talent shortage. In that regard, we introduce a comprehensive model on value creation that uses the KBV as theoretical foundation. Our model enriches the conceptual understanding of SCM competencies because the existing literature has neither differentiated between individual and organizational aspects of SCM competencies nor investigated their separate contributions to SCM performance. We find evidence that organizational SCM knowledge and individual SCM competencies fulfill the value propositions conceptualized in the KBV by recognizing them as VRIN. Therefore, both knowledge components qualify as a potentially competitive advantage. More specifically, our results suggest that both components are important to drive performance. We accordingly draw the conclusion that the characteristics and pre-requisites of these components should be studied with additional research. 
Probably even more importantly, we investigate how both dimensions of competencies can be facilitated and enhanced, thereby following up on previous work of organizational learning and training in SCM (Ellinger and Ellinger, 2014; Hult et al., 2003). Here, the literature is extended in two ways: First, we show that the positive effect of training on individual competencies is surprisingly limited. This finding contradicts previous results (e.g., Ahmad and Schroeder, 2003). Secondly, previous research on organizational learning in SCM is further elaborated. In contrast to previous studies that investigated the (more obvious) direct effects on various performance metrics, this study shows a strong indirect effect via generating organizational knowledge or facilitating the upskilling of SCM personnel. Our paper adds a deeper level of understanding the multi-dimensional facets of organizational learning in SCM context and also suggests that organizational learning and its prerequisites are essential indirect enablers of SCM performance. In sum, our paper shows that all selected concepts should not be treated as isolated elements. Rather, they are connected. Thus, our comprehensive model extends previous research that had investigated these concepts separately.

\section{Managerial implications}

The study's findings have three managerial implications. Firstly, the fact that individual and organizational SCM knowledge components affect performance indicators to similar degrees emphasizes that companies cannot afford to focus on developing only one. Rather, companies must develop cohesive strategies to improve both dimensions hand-in-hand. Such strategies appear particularly crucial in the current era of digitalization, which is revolutionizing the way organizations learn (i.e., how they acquire, distribute and absorb information). The availability and richness of big data and the opportunity to perform more advanced analyses bear tremendous potential for creating new organizational knowledge. However, SCM personnel need the right 
competencies to filter relevant from irrelevant information, apply the appropriate analytical methods and draw the right conclusions. Having all the organizational knowledge at hand but nonqualified personnel leaves significant potential for SCM performance improvement untapped. This situation leads to the second implication, indicating the strong linkage of our conceptual models:

The results of this study suggest that corporate training programs in general are relatively ineffective at developing the required supply chain personnel competencies and therefore require improvement. We suggest that companies improve their training activities by consulting external resources that are specialized in SCM training program design. Again, digital technologies present new opportunities for improving SCM training by leveraging e-learning platforms, mobile access to training materials, and virtual classrooms to globally connect knowledgeable teachers with the personnel that need training easily and at affordable costs (McKinnon et al., 2017). Additionally, "the opportunity to develop" is a key requirement for most job applicants and strongly drives employee satisfaction. In light of the shortage of qualified SCM personnel, the SCM function cannot afford to ignore this essential criterion for triggering job applications from talent.

Third, organizational learning's strong and direct and indirect contribution has two implications for SCM: (i) Organizational learning should serve as a motivation for constantly improving the information acquisition, distribution and absorption processes; and (ii) information only taps its true potential for enhancing SCM performance if it first elevates individual competencies and organizational knowledge.

\section{Limitations and future research}

This study is subject to certain limitations. Due to the complexity of the conceptual model featuring three second-level factors, all first-level factors of organizational learning and knowledge provided in the literature could not be incorporated. Nevertheless, we are confident 
that our model captured all of the relevant first-level factors. Moreover, the complexity of the topic also prevented us from including all HRM practices in our model. In response, future research could shift to focus on the impact of other HRM practices on SCM performance such as managing employee behavior, selecting employees and defining job positions. Due to the anonymous nature of the survey, we could not obtain objective and secondary data for measuring the SCM performance of the companies involved. Instead, we relied on subjective respondent information. However, previous research has shown that the performance data obtained through surveys are reasonably reliable compared with actual key performance indicators (Carr and Pearson, 1999). We only addressed potential non-response bias by using late respondents as a proxy instead of real non-respondents. Additionally, the majority of our respondents work for major corporations with over 10,000 employees. This situation means that our results might not necessarily be generalizable to small- or medium-sized companies that operate on different organizational structures.

Aside from the limitations stated above, the study opens up various avenues for further research. Because we found a heavy bias towards American companies in the SCM and HRM literature, more knowledge on the impact of HRM practices in non-American companies' SCM is needed. Due to the lack of academic and public studies on HRM practices in Europe, we were only able to discuss the limited investments and efforts put into SCM training based on the study by Gibson et al. (2013) of American firms.

Furthermore, because this study used an online survey, only a snapshot of a current state was captured. Consequently, a longitudinal, in-depth case study including multiple companiesespecially one revealing the dynamic development of SCM competencies-would be a highly interesting avenue for further research. For instance, qualitative studies of companies that are 
restructuring their employee development programs to observe and measure key improvement factors over time will be valuable to both research and practice. A particularly important aspect, given the results of this paper, is further research on best practices in topics, methods and impact of SCM training programs. It is essential to understand if and how to leverage trainings for improving individual SCM competencies. Finally, studying the exchange of knowledge and joint organizational learning in supplier-buyer dyads will help to reveal the impact of these factors across company boundaries, thereby extending inter-organizational SCM competency development and our understanding of it.

\section{REFERENCES}

Aguinis, H., and Kraiger, K., (2009), "Benefits of training and development for individuals and teams, organizations, and society", Annual Review of Psychology, Vol. 60, pp. 451-474.

Ahire, S., Golhar, D., and Waller, M., (1996), "Development and validation of TQM implementation constructs", Decision Sciences, Vol. 27 No. 1, pp. 23-56.

Ahmad, S., and Schroeder, R.G., (2003), "The impact of human resource management practices on operational performance: recognizing country and industry differences", Journal of Operations Management, Vol. 21 No. 1, pp. 19-43.

Anderson, J., and Gerbing, D., (1988), "Structural equation modeling in practice: a review and recommended two-step approach", Psychological Bulletin, Vol. 103 No. 3, pp. 411-423.

Autio, E., Sapienza, H.J., and Almeida, J.G., (2000), "Effects of age at entry, knowledge intensity, and imitability on international growth", Academy of Management Journal, Vol. 43 No. 5, pp. 909-924.

Barney, J.B., (1991), "Firm resources and sustained competitive advantage", Journal of Management, Vol. 17 No. 1, pp. 99-120.

Bollen, K.A., (1989), Structural Equations with Latent Variables, Wiley, New York, NY.

Bollen, K.A., and Stine, R., (1990), "Direct and indirect effects: classical and bootstrap estimates of variability", in Clogg, C. C. (Ed.), Sociological Methodology, Blackwell, Oxford, UK, pp. 115-140.

Bozarth, C.C., Warsing, D.P., Flynn, B.B., and Flynn, E.J., (2009), "The impact of supply chain complexity on manufacturing plant performance", Journal of Operations Management, Vol. 27 No. 1, pp. 78-93.

Byrd, T., and Turner, D., (2001), "An exploratory analysis of the value of the skills of IT personnel: their relationship to IS infrastructure and competitive advantage", Decision Sciences, Vol. 32 No. 1, pp. 21-54.

Cao, M., and Zhang, Q., (2011), "Supply chain collaboration: impact on collaborative advantage and firm performance", Journal of Operations Management, Vol. 29 No. 3, pp. 163-180. 
Carr, A.S., and Pearson, J.N., (1999), "Strategically managed buyer-supplier relationships and performance outcomes", Journal of Operations Management, Vol. 17 No. 5, pp. 497-519.

Chin, W.W., (1998), "Issues and opinion on structural equation modeling.", MIS Quarterly, Vol. 22 No. 1, pp. vii-xvi.

Cooper, M.C., Lambert, D.M., and Pagh, J.D., (1997), "Supply chain management: more than a new name for logistics", The International Journal of Logistics Management, Vol. 8 No. 1, pp. $1-14$.

Cottrill, K., (2010), "Are you prepared for the supply chain talent crisis?", MIT Center for Transportation and Logistics, MIT CTL White Paper, Vol. Fall, pp. 1-11.

Craighead, C.W., Hult, G.T.M., and Ketchen Jr., D.J., (2009), "The effects of innovation-cost strategy, knowledge, and action in the supply chain on firm performance", Journal of Operations Management, Vol. 27 No. 5, pp. 405-421.

Cronbach, L.J., (1951), "Coefficient alpha and the internal structure of tests", Psychometrika, Vol. 16 No. 3, pp. 297-334.

Davenport, T.H., and Prusak, L., (1998), Working Knowledge, Harvard Business School Press, Boston.

Derwik, P., and Hellström, D., (2017), "Competence in supply chain management: a systematic review", Supply Chain Management: An International Journal, Vol. 22 No. 2.

Deshpande, R., and Zaltman, G., (1982), "Factors affecting the use of market research information: a path analysis", Journal of Marketing Research, Vol. 19 No. 1, pp. 14-31.

Devaraj, S., Krajewski, L., and Wei, J., (2007), "Impact of eBusiness technologies on operational performance: the role of production information integration in the supply chain", Journal of Operations Management, Vol. 25 No. 6, pp. 1199-1216.

DiBella, A., Nevis, E., and Gould, J., (1996), "Understanding organizational learning capability", Journal of Management Studies, Vol. 33 No. 3, pp. 361-379.

Dröge, C., Jayaram, J., and Vickery, S.K., (2004), "The effects of internal versus external integration practices on time-based performance and overall firm performance", Journal of Operations Management, Vol. 22 No. 6, pp. 557-573.

Eisenhardt, K.M., and Martin, J.A., (2000), "Dynamic capabilities: what are they?", Strategic Management Journal, Vol. 21 No. 10-11, pp. 1105-1121.

Ellinger, A.E., and Ellinger, A.D., (2014), "Leveraging human resource development expertise to improve supply chain managers' skills and competencies", European Journal of Training and Development, Vol. 38 No. 1/2, pp. 118-135.

Ellinger, A.E., Ketchen Jr., D.J., Hult, G.T.M., Elmadag, A.B., and Richey, R.G., (2008), "Market orientation, employee development practices, and performance in logistics service provider firms", Industrial Marketing Management, Vol. 37 No. 4, pp. 353-366.

Ellinger, A.E., Natarajarathinam, M., Adams, F.G., Gray, J.B., Hofman, D., and O’Marah, K., (2011), "Supply chain management competency and firm financial success", Journal of Business Logistics, Vol. 32 No. 3, pp. 214-226.

Eroglu, C., and Hofer, C., (2011), "Lean, leaner, too lean? The inventory-performance link revisited", Journal of Operations Management, Vol. 29 No. 4, pp. 356-369.

Fawcett, S.E., and Waller, M.A., (2013), "Considering supply chain management's professional identity: the beautiful discipline (or,"we don't cure cancer, but we do make a big difference")", Journal of Business Logistics, Vol. 34 No. 3, pp. 183-188.

Felin, T., and Hesterly, W., (2007), "The knowledge-based view, nested heterogeneity, and new value creation: philosophical considerations on the locus of knowledge", Academy of Management Review, Vol. 32 No. 1, pp. 195-218. 
Fisher, S.L., Graham, M.E., Vachon, S., and Vereecke, A., (2010), "Guest editors' note: don't miss the boat: research on HRM and supply chains", Human Resource Management, Vol. 49 No. 5, pp. 813-828.

Flores, L.G., Zheng, W., Rau, D., and Thomas, C.H., (2010), "Organizational learning: subprocess identification, construct validation, and an empirical test of cultural antecedents", Journal of Management, Vol. 38 No. 2, pp. 640-667.

Flöthmann, C., and Hoberg, K., (2017), "Career patterns of supply chain executives: an optimal matching analysis", Journal of Business Logistics, Vol. 38 No. 1, pp. 35-54.

Forbes (2015), Spending on corporate training soars: employee capabilities now a priority,. http://www.forbes.com/sites/joshbersin/2014/02/04/the-recovery-arrives-corporate-trainingspend-skyrockets/, Accessed July 11, 2015,.

Fornell, C., and Larcker, D.F., (1981), "Evaluating structural equation models with unobservable variables and measurement error", Journal of Marketing Research, Vol. 18 No. 1, pp. 39-50.

Fowler, F.J., (2014), Survey research methods, 5th ed., Sage Publications Inc., Thousand Oaks, $\mathrm{Ca}$.

Gammelgaard, B., and Larson, P.D., (2001), "Logistics skills and competencies for supply chain management", Journal of Business Logistics, Vol. 22 No. 2, pp. 27-50.

Gerbing, D.W., and Anderson, J.C., (1988), "An updated paradigm for scale development incorporating unidimensionality and its assessment", Journal of Marketing Research, Vol. 25 No. 2, pp. 186-192.

Gibson, B.J., Williams, Z., Goffnett, S., and Cook, R.L., (2013), SCM Talent Development: the Develop Process, Council of Supply Chain Management Professionals, Oak Brook, IL.

Giunipero, L.C., and Pearcy, D.H., (2000), "World-class purchasing skills: an empirical investigation", Journal of Supply Chain Management, Vol. 36 No. 4, pp. 4-13.

Gowen, C.R., and Tallon, W.J., (2003), "Enhancing supply chain practices through human resource management", Journal of Management Development, Vol. 22 No. 1, pp. 32-44.

Grant, R., (1996), "Toward a knowledge-based theory of the firm", Strategic Management Journal, Vol. 17 No. S2, pp. 109-122.

Guide Jr., V.D.R., and Ketokivi, M., (2015), "Notes from the Editors: redefining some methodological criteria for the journal", Journal of Operations Management, Vol. 37 No. July, pp. v-viii.

Gunasekaran, A., and Kobu, B., (2007), "Performance measures and metrics in logistics and supply chain management: a review of recent literature (1995-2004) for research and applications", International Journal of Production Research, Vol. 45 No. 12, pp. 2819-2840.

Hair, J.F., Black, W.C., Babin, B.J., Anderson, R.E., and Tatham, R.L., (2010), Multivariate Data Analysis, 7th ed., Pearson Prentice Hall, Upper Saddle River, NJ.

Hélie, S., and Sun, R., (2010), "Incubation, insight, and creative problem solving: a unified theory and a connectionist model", Psychological Review, Vol. 117 No. 3, pp. 994-1024.

Hohenstein, N.-O., Feisel, E., and Hartmann, E., (2014), "Human resource management issues in supply chain management research: a systematic literature review from 1998 to 2014", International Journal of Physical Distribution \& Logistics Management, Vol. 44 No. 6, pp. 434-463.

$\mathrm{Hu}, \mathrm{L}$. , and Bentler, P.M., (1999), "Cutoff criteria for fit indexes in covariance structure analysis: conventional criteria versus new alternatives", Structural Equation Modeling: A Multidisciplinary Journal, Vol. 6 No. 1, pp. 1-55.

Hult, G.T.M., (1998), "Managing the international strategic sourcing process as a market-driven organizational learning system", Decision Sciences, Vol. 29 No. 1, pp. 193-214. 
Hult, G.T.M., Hurley, R.F., Giunipero, L.C., and Nichols Jr., E.L., (2000), "Organizational learning in global purchasing: a model and test of internal users and corporate buyers", Decision Sciences, Vol. 31 No. 2, pp. 293-325.

Hult, G.T.M., Ketchen Jr., D.J., and Arrfelt, M., (2007), "Strategic supply chain management: improving performance through a culture of competitiveness and knowledge development", Strategic Management Journal, Vol. 28 No. 10, pp. 1035-1052.

Hult, G.T.M., Ketchen Jr., D.J., Cavusgil, S.T., and Calantone, R.J., (2006), "Knowledge as a strategic resource in supply chains", Journal of Operations Management, Vol. 24 No. 5, pp. $458-475$.

Hult, G.T.M., Ketchen Jr., D.J., and Nichols Jr., E.L., (2003), "Organizational learning as a strategic resource in supply management", Journal of Operations Management, Vol. 21 No. 5 , pp. 541-556.

Hult, G.T.M., Ketchen Jr., D.J., and Slater, S.F., (2004), "Information processing, knowledge development, and strategic supply chain performance", Academy of Management Journal, Vol. 47 No. 2, pp. 241-253.

Huselid, M.A., (1995), "The impact of human resource management practices on turnover, productivity, and corporate financial performance", Academy of Management Journal, Vol. 38 No. 3, pp. 635-672.

Iacobucci, D., (2010), "Structural equations modeling: fit indices, sample size, and advanced topics", Journal of Consumer Psychology, Vol. 20 No. 1, pp. 90-98.

Jayaram, J., Dröge, C., and Vickery, S., (1999), "The impact of human resource management practices on manufacturing performance", Journal of Operations Management, Vol. 18 No. 1 , pp. 1-20.

John, G., (2015), Developing Supply Chain Capability - Findings of the Talent Survey 2015, SCM World, London.

Kline, R.B., (2011), Principles and Practice of Structural Equation Modeling, 3rd ed., The Guilford Press, New York.

Kogut, B., and Zander, U., (1992), "Knowledge of the firm, combinative capabilities, and the replication of technology", Organization Science, Vol. 3 No. 3, pp. 383-397.

Lambert, D.M., and Harrington, T.C., (1990), "Measuring nonresponse bias in customer service mail surveys", Journal of Business Logistics, Vol. 11 No. 2, pp. 5-25.

Lawler, E.E., (1994), "From job-based to competency-based organizations", Journal of Organizational Behavior, Vol. 15 No. 1, pp. 3-15.

Lee, H.L., Padmanabhan, V., and Whang, S., (1997), "Information distortion in a supply chain: the bullwhip effect", Management Science, Vol. 43 No. 4, pp. 546-558.

Leonard-Barton, D., (1992), "The factory as a learning laboratory", Sloan Management Review, Vol. 34 No. 1, pp. 23-38.

Malhotra, M.K., Singhal, C., Shang, G., and Ployhart, R.E., (2014), "A critical evaluation of alternative methods and paradigms for conducting mediation analysis in operations management research", Journal of Operations Management, Vol. 32 No. 3, pp. 127-137.

McAfee, R., Glassmann, M., and Honeycutt, E.D., (2002), "The effects of culture and human resource management policies on supply chain management strategy", Journal of Business Logistics, Vol. 23 No. 1, pp. 1-18.

McKinnon, A.C., Flöthmann, C., Hoberg, K., and Busch, C., (2017), Logistics competencies, skills, and training: a global overview, World Bank, World Bank Studies, Washington DC.

Mirabile, R.J., (1997), "Everything you wanted to know about competency modeling", Training and Development, Vol. 51 No. 8, pp. 73-77. 
Murphy, P.R., and Poist, R.F., (2007), "Skill requirements of senior-level logisticians: a longitudinal assessment", Supply Chain Management: An International Journal, Vol. 12 No. 6, pp. 423-431.

Murphy, P.R., and Poist, R.F., (1991), "Skill requirements of senior-level logistics executives: an empirical investigation", Journal of Business Logistics, Vol. 12 No. 2, pp. 73-95.

Myers, M.B., Griffith, D.A., Daugherty, P.J., and Lusch, R.F., (2004), "Maximizing the human capital equation in logistics: education, experience, and skills", Journal of Business Logistics, Vol. 25 No. 1, pp. 211-232.

Nahapiet, J., and Ghoshal, S., (1998), "Social capital, intellectual capital, and the organizational advantage", Academy of Management Review, Vol. 23 No. 2, pp. 242-266.

Narasimhan, R., and Das, A., (2001), "The impact of purchasing integration and practices on manufacturing performance", Journal of Operations Management, Vol. 19 No. 5, pp. 593609.

Nass, C., (1994), "Knowledge or skills: which do administrators learn from experience?", Organization Science, Vol. 5 No. 1, pp. 38-50.

Nonaka, I., (1991), "The knowledge-creating company", Harvard Business Review, Vol. 69 No. 6, pp. 96-104.

O'Reilly, C.A., (1980), "Variations in decision makers' use of information sources: the impact of quality and accessibility of information", Academy of Management Proceedings, Vol. 8 No. 1, pp. 183-187.

Podsakoff, P.M., MacKenzie, S.B., Lee, J.-Y., and Podsakoff, N.P., (2003), "Common method biases in behavioral research: a critical review of the literature and recommended remedies.", Journal of Applied Psychology, Vol. 88 No. 5, pp. 879-903.

Rexhausen, D., Pibernik, R., and Kaiser, G., (2012), "Customer-facing supply chain practices - the impact of demand and distribution management on supply chain success", Journal of Operations Management, Vol. 30 No. 4, pp. 269-281.

Schoenherr, T., Griffith, D.A., and Chandra, A., (2014), "Knowledge management in supply chains: the role of explicit and tacit knowledge", Journal of Business Logistics, Vol. 35 No. 2, pp. 121-135.

Simon, H.A., (1991), "Bounded rationality and organizational learning", Organization Science, Vol. 2 No. 1, pp. 125-134.

Slone, R., Mentzer, J., and Dittmann, J., (2007), "Are you the weakest link in your company's supply chain?", Harvard Business Review, Vol. 85 No. 9, pp. 116-127.

Spekman, R.E., Spear, J., and Kamauff, J., (2002), "Supply chain competency: learning as a key component", Supply Chain Management: An International Journal, Vol. 7 No. 1, pp. 41-55.

Sweeney, E., (2013), "The people dimension in logistics and supply chain management - its role and importance", in Passaro, R. and Thomas, A. (Ed.), Supply Chain Management: Perspectives, Issues and Cases, McGraw-Hill, Milan, pp. 73-82.

Terjesen, S., Patel, P.C., and Covin, J.G., (2011), "Alliance diversity, environmental context and the value of manufacturing capabilities among new high technology ventures", Journal of Operations Management, Vol. 29 No. 1-2, pp. 105-115.

Tippins, M., and Sohi, R., (2003), "IT competency and firm performance: is organizational learning a missing link?", Strategic Management Journal, Vol. 24 No. 8, pp. 745-761.

van der Vaart, T., and van Donk, D.P., (2008), "A critical review of survey-based research in supply chain integration", International Journal of Production Economics, Vol. 111 No. 1, pp. $42-55$.

Vickery, S.K., Jayaram, J., Dröge, C., and Calantone, R., (2003), "The effects of an integrative 
supply chain strategy on customer service and financial performance: an analysis of direct versus indirect relationships", Journal of Operations Management, Vol. 21 No. 5, pp. 523539.

Vidal-Salazar, M., Cordón-Pozo, E., and Ferrón-Vilchez, V., (2012), "Human resource management and developing proactive environmental strategies: the influence of environmental training and organizational learning", Human Resource Management, Vol. 51 No. 6, pp. 905-934.

Voorhees, C.M., Brady, M.K., Calantone, R., and Ramirez, E., (2016), "Discriminant validity testing in marketing: an analysis, causes for concern, and proposed remedies", Journal of the Academy of Marketing Science, Vol. 44 No. 1, pp. 119-134.

Wagner, S.M., Grosse-Ruyken, P.T., and Erhun, F., (2012), "The link between supply chain fit and financial performance of the firm", Journal of Operations Management, Vol. 30 No. 4, pp. 340-353.

Wagner, S.M., and Kemmerling, R., (2010), "Handling nonresponse in logistics research", Journal of Business Logistics, Vol. 31 No. 2, pp. 357-382.

Wernerfelt, B., (1984), "A resource-based view of the firm", Strategic Management Journal, Vol. 5 No. 2, pp. 171-180. 


\section{APPENDIX A: RESULTS FROM CFA - SUMMARY}

\section{DATA FOR INDIVIDUAL CONSTRUCT ITEMS}

\begin{tabular}{|c|c|c|}
\hline Construct items & $\begin{array}{c}\text { Standardized } \\
\text { estimates } \\
\text { (factor loadings) }\end{array}$ & $\begin{array}{c}\text { t-values } \\
\text { (all significant at } \\
\mathbf{p}<\mathbf{0 . 0 0 1} \text { ) }\end{array}$ \\
\hline $\begin{array}{c}\text { ORGANIZATIONAL } \\
\text { LEARNING } \\
\text { Information Distribution } \\
\text { IDIST1 }\end{array}$ & 0.744 & 9.316 \\
\hline IDIST2 & 0.672 & 13.232 \\
\hline IDIST3 & 0.926 & 24.053 \\
\hline Information Acquisition & 0.931 & $--{ }^{\text {a) }}$ \\
\hline IACQ1 & 0.857 & -- \\
\hline IACQ2 & 0.567 & 8.692 \\
\hline IACQ3 & 0.814 & 11.841 \\
\hline Information Absorption & 0.778 & -- \\
\hline IABSO1 & 0.775 & 8.622 \\
\hline IABSO2 & 0.686 & 10.258 \\
\hline IABSO3 & 0.728 & 11.841 \\
\hline
\end{tabular}

\begin{tabular}{|c|c|c|}
\hline Construct items & $\begin{array}{c}\text { Standardized } \\
\text { estimates } \\
\text { (factor loadings) }\end{array}$ & $\begin{array}{c}\text { t-values } \\
\text { (all significant at } \\
\mathbf{p}<\mathbf{0 . 0 0 1 )}\end{array}$ \\
\hline $\begin{array}{c}\text { INDIVIDUAL SCM } \\
\text { COMPETENCIES } \\
\text { SCM Core Competency } \\
\text { CSCM1 }\end{array}$ & \\
\hline CSCM2 & 0.988 & -- \\
\hline CSCM3 & 0.776 & -- \\
\hline Managerial Competency & 0.717 & 12.500 \\
\hline CMGMT1 & 0.690 & 12.009 \\
\hline CMGMT2 & 0.854 & 11.758 \\
\hline CMGMT3 & 0.809 & -- \\
\hline IT Competency & 0.757 & 13.234 \\
\hline CIT1 & 0.670 & 11.357 \\
\hline CIT2 & 0.709 & -- \\
\hline CIT3 & 0.854 & 10.487 \\
\hline & 0.875 & 15.438 \\
\hline
\end{tabular}

\begin{tabular}{|c|c|c|}
\hline $\begin{array}{c}\text { Corporate Training } \\
\text { TRAIN1 }\end{array}$ & 0.783 & 13.543 \\
\hline TRAIN2 & 0.843 & 14.396 \\
\hline TRAIN3 & 0.802 & 13.795 \\
\hline TRAIN4 & 0.792 & -- \\
\hline $\begin{array}{c}\text { SCM Performance } \\
\text { SCMP1 }\end{array}$ & 0.542 & 8.135 \\
\hline SCMP2 & 0.653 & 9.808 \\
\hline SCMP3 & 0.643 & 9.629 \\
\hline SCMP4 & 0.652 & -- \\
\hline SCMP5 & 0.831 & 12.013 \\
\hline SCMP6 & 0.921 & 12.196 \\
\hline
\end{tabular}

\begin{tabular}{|c|c|c|}
\hline $\begin{array}{c}\text { ORGANIZATIONAL SCM } \\
\text { KNOWLEDGE }\end{array}$ & & \\
Knowledge Access & 0.682 & -- \\
KACC1 & 0.909 & -- \\
\hline KACC2 & 0.781 & 14.925 \\
\hline KACC3 & 0.764 & 14.447 \\
\hline Knowledge Intensity & 0.852 & 9.040 \\
KINTENS1 & 0.842 & 17.406 \\
\hline KINTENS2 & 0.907 & 19.943 \\
\hline KINTENS3 & 0.865 & -- \\
\hline Knowledge Use & 0.816 & 8.937 \\
KUSE1 & 0.819 & 16.570 \\
\hline KUSE2 & 0.878 & 18.679 \\
\hline KUSE3 & 0.878 & -- \\
\hline
\end{tabular}

Notes: $2^{\text {nd }}$ order constructs in capitals

a) -- indicates a factor loading that was fixed to 1.0 for identification purposes t-values from unstandardized solution

Measurement model is estimated using maximum likelihood 


\begin{tabular}{|c|c|c|}
\hline \multicolumn{3}{|c|}{ CORE QUESTION ITEMS \& CONSTRUCTS - INPUT VARIABLES OF SEM ANALYSIS } \\
\hline Item & $\begin{array}{c}\text { Question text }- \text { All answers on 7-point Likert scale } \\
\text { Standard scale: } 1 \text { = Strongly disagree, } 7=\text { Strongly agree }\end{array}$ & References \\
\hline \multicolumn{3}{|l|}{ Knowledge Access } \\
\hline KACC1 & $\begin{array}{l}\text { SCM knowledge contained in our organization is very easily accessible when } \\
\text { needed. }\end{array}$ & \multirow{3}{*}{$\begin{array}{l}\text { (O'Reilly, 1980; Hult et } \\
\text { al., 2006) }\end{array}$} \\
\hline $\mathrm{KACC} 2$ & $\begin{array}{l}\text { On average, it is very easy to obtain SCM knowledge from key people in this } \\
\text { organization. }\end{array}$ & \\
\hline KACC3 & $\begin{array}{l}\text { On average, it is very easy to obtain SCM knowledge from databases and } \\
\text { documentation in our organization. }\end{array}$ & \\
\hline Knowledge Intensity & In our organization... & \\
\hline KINTENS1 & ...knowledge intensity is a main characteristic of our SCM practices. & \multirow{3}{*}{$\begin{array}{l}\text { (Autio et al., 2000; Hult et } \\
\text { al., 2006) }\end{array}$} \\
\hline KINTENS2 & ...there is a strong knowledge component in our SCM practices. & \\
\hline KINTENS3 & ...knowledge of SCM practices is one of our greatest strengths. & \\
\hline Knowledge Use & Our existing organizational knowledge... & \\
\hline KUSE1 & $\begin{array}{l}\text {...identifies aspects of our latest SCM activity that would otherwise have gone } \\
\text { unnoticed. }\end{array}$ & \multirow{3}{*}{$\begin{array}{l}\text { (Deshpande and Zaltman, } \\
\text { 1982; Hult et al., 2006) }\end{array}$} \\
\hline KUSE2 & ...enables us to make specific decisions for our latest SCM activity. & \\
\hline KUSE3 & ...enriches the basic understanding of our latest SCM activity. & \\
\hline SCM Performance & $\begin{array}{l}\text { How do you rank your supply chain performance compared to your best } \\
\text { competitors in terms of... } 1=\text { Much worse, } 7=\text { Much better }\end{array}$ & \\
\hline SCMP1 & 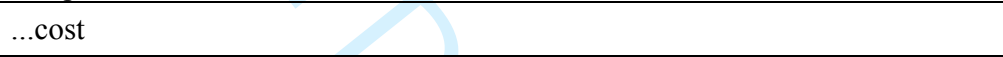 & \multirow{6}{*}{$\begin{array}{l}\text { (Fawcett and Waller, } \\
\text { 2013; Gunasekaran and } \\
\text { Kobu, 2007; Narasimhan } \\
\text { and Das, 2001; Rexhausen } \\
\text { et al., 2012) }\end{array}$} \\
\hline SCMP2 &  & \\
\hline SCMP3 & ...responsiveness & \\
\hline SCMP4 & ...innovation & \\
\hline SCMP5 & ...improvement (of overall supply chain performance) & \\
\hline SCMP6 & ...overall supply chain performance & \\
\hline \multicolumn{3}{|l|}{ Information Distribution } \\
\hline IDIST1 & Lessons learned by one group are frequently shared by others. & \multirow{3}{*}{ (Flores et al., 2010) } \\
\hline IDIST2 & $\begin{array}{l}\text { Our company has effective processes for exchanging information between } \\
\text { individuals. }\end{array}$ & \\
\hline IDIST3 & $\begin{array}{l}\text { Our company has effective processes to distribute information throughout the } \\
\text { organization. }\end{array}$ & \\
\hline \multicolumn{3}{|l|}{ Information Acquisition } \\
\hline IACQ1 & We constantly benchmark ourselves with our competitors. & \multirow{3}{*}{ (Flores et al., 2010) } \\
\hline IACQ2 & We always acquire relevant information from outside our company. & \\
\hline IACQ3 & We always develop new knowledge from existing knowledge. & \\
\hline \multicolumn{3}{|l|}{ Information Absorption } \\
\hline IABSO1 & $\begin{array}{l}\text { Top management always integrates information from different organizational } \\
\text { areas. }\end{array}$ & \multirow{3}{*}{ (Flores et al., 2010) } \\
\hline IABSO2 & Our employees meet frequently to resolve issues and concerns. & \\
\hline IABSO3 & $\begin{array}{l}\text { Our company always motivates sharing and trying to understand management } \\
\text { vision through communication with colleagues. }\end{array}$ & \\
\hline IT Competency & Our SCM personnel are very skilled... & \\
\hline CIT1 & ...in working with databases. & \multirow{3}{*}{$\begin{array}{l}\text { (Gammelgaard and } \\
\text { Larson, 2001; Murphy } \\
\text { and Poist, 1991; Murphy } \\
\text { and Poist, 2007; } \\
\text { Giunipero and Pearcy, }\end{array}$} \\
\hline CIT2 & ...in working with large amount of data. & \\
\hline CIT3 & ...in working with decision-support systems. & \\
\hline
\end{tabular}




\begin{tabular}{|c|c|c|}
\hline \multicolumn{3}{|c|}{ CORE QUESTION ITEMS \& CONSTRUCTS - INPUT VARIABLES OF SEM ANALYSIS } \\
\hline Item & $\begin{array}{c}\text { Question text }- \text { All answers on } 7 \text {-point Likert scale } \\
\text { Standard scale: } 1 \text { = Strongly disagree, } 7=\text { Strongly agree }\end{array}$ & References \\
\hline 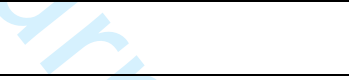 & & $\begin{array}{l}\text { 2000; Byrd and Turner } \\
\text { 2001) }\end{array}$ \\
\hline Management Competency & Our SCM personnel have excellent skills... & \\
\hline CMGMT1 & ...to plan, organize, and lead projects. & \multirow{3}{*}{$\begin{array}{l}\text { (Gammelgaard and } \\
\text { Larson, 2001; Murphy } \\
\text { and Poist, 1991; Murphy } \\
\text { and Poist, 2007; } \\
\text { Giunipero and Pearcy, } \\
\text { 2000; Byrd and Turner } \\
\text { 2001) }\end{array}$} \\
\hline CMGMT2 & ...to execute work in a team. & \\
\hline CMGMT3 & ...to accomplish multiple assignments. & \\
\hline SCM Core Competency & Our SCM personnel... & \\
\hline CSCM1 & ...have excellent skills in analyzing our supply chain processes. & \multirow{3}{*}{$\begin{array}{l}\text { (Gammelgaard and } \\
\text { Larson, 2001; Murphy } \\
\text { and Poist, 1991; Murphy } \\
\text { and Poist, 2007; } \\
\text { Giunipero and Pearcy, } \\
\text { 2000; Byrd and Turner } \\
\text { 2001) }\end{array}$} \\
\hline CSCM2 & ...have excellent skills in managing information flows. & \\
\hline CSCM3 & ...possess a strong cross-functional awareness. & \\
\hline \multicolumn{3}{|l|}{ Corporate Training } \\
\hline TRAIN1 & $\begin{array}{l}\text { Employees in the SCM department receive training and development in } \\
\text { relevant competencies frequently. }\end{array}$ & \multirow{4}{*}{$\begin{array}{l}\text { (Ahmad and Schroeder, } \\
\text { 2003) }\end{array}$} \\
\hline TRAIN2 & $\begin{array}{l}\text { Human resource management promotes comprehensive training of our SCM } \\
\text { employees. }\end{array}$ & \\
\hline TRAIN3 & Relevant training is part of the company's talent program. & \\
\hline TRAIN4 & Resources are always available for employee training in our SCM department. & \\
\hline \multirow[t]{2}{*}{$\begin{array}{l}\text { Marker Variable for CMB } \\
\text { Testing }\end{array}$} & Please indicate the strategic supply chain priorities for the main product line & \multirow{2}{*}{ Wagner et al. (2012) } \\
\hline & We always maintain buffer inventory of parts or finished goods. & \\
\hline
\end{tabular}

\begin{tabular}{|c|c|c|}
\hline \multicolumn{3}{|c|}{ DEMOGRAPHIC QUESTIONS } \\
\hline $\begin{array}{c}\text { Demographic } \\
\text { Scope }\end{array}$ & Question & Scale \\
\hline $\begin{array}{l}\text { Business } \\
\text { Experience }\end{array}$ & $\begin{array}{l}\text { How many years of professional experience } \\
\text { do you have (without apprenticeships or } \\
\text { internships)? }\end{array}$ & $\begin{array}{l}\text { less than } 2 \\
>2-5 \\
>5-10 \\
>10-25 \\
\text { more than } 25 \\
\end{array}$ \\
\hline $\begin{array}{l}\text { Company } \\
\text { Experience }\end{array}$ & $\begin{array}{l}\text { How many years have you worked for your } \\
\text { current employer? }\end{array}$ & $\begin{array}{l}\text { less than } 2 \\
>2-5 \\
>5-10 \\
>10-25 \\
\text { more than } 25 \\
\end{array}$ \\
\hline Industry & $\begin{array}{l}\text { In which industry does your current company } \\
\text { operate? (if you are employed in a major } \\
\text { enterprise operating in multiple industries, } \\
\text { please indicate the sector of your BU.) }\end{array}$ & Industry classification benchmark \\
\hline $\begin{array}{l}\text { Company } \\
\text { Employees }\end{array}$ & $\begin{array}{l}\text { How many employees work for your } \\
\text { company? }\end{array}$ & $\begin{array}{l}1-50 \\
51-500 \\
501-1,000 \\
1,001-10,000 \\
\text { more than } 10,000 \\
\end{array}$ \\
\hline $\begin{array}{l}\text { Company } \\
\text { Revenue }\end{array}$ & $\begin{array}{l}\text { What was the approx. revenue of your } \\
\text { company last years? }\end{array}$ & $\begin{array}{l}\text { below } 10 \mathrm{mn} \\
10-250 \mathrm{mn} \\
>250 \mathrm{mn}-1 \mathrm{bn}\end{array}$ \\
\hline
\end{tabular}




\begin{tabular}{|c|c|c|}
\hline \multicolumn{3}{|c|}{ DEMOGRAPHIC QUESTIONS } \\
\hline $\begin{array}{l}\text { Demographic } \\
\text { Scope }\end{array}$ & Question & Scale \\
\hline 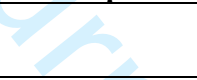 & & $\begin{array}{l}>1-10 \mathrm{bn} \\
\text { above 10bn }\end{array}$ \\
\hline $\begin{array}{l}\text { Hierarchical } \\
\text { level }\end{array}$ & Which management level applies to you best? & $\begin{array}{l}\text { Top management (e.g., CSCO, COO, managing director) } \\
\text { Middle management (e.g., VP, division leader, head of department) } \\
\text { Lower management (e.g., team leader, project manager) } \\
\text { No management level (e.g., specialist, expert) } \\
\text { Other }\end{array}$ \\
\hline Country & $\begin{array}{l}\text { In which country/region do you work the } \\
\text { majority of your time? }\end{array}$ & List of all UN member states \\
\hline $\begin{array}{l}\text { Personnel } \\
\text { responsibility }\end{array}$ & $\begin{array}{l}\text { How many persons are reporting directly to } \\
\text { you? }\end{array}$ & $\begin{array}{l}1 \text { to } 4 \\
5 \text { to } 14 \\
15 \text { to } 49 \\
50 \text { to } 100 \\
\text { more than } 100\end{array}$ \\
\hline
\end{tabular}




\section{Conceptual Model: factors and hypotheses - Figure 1}

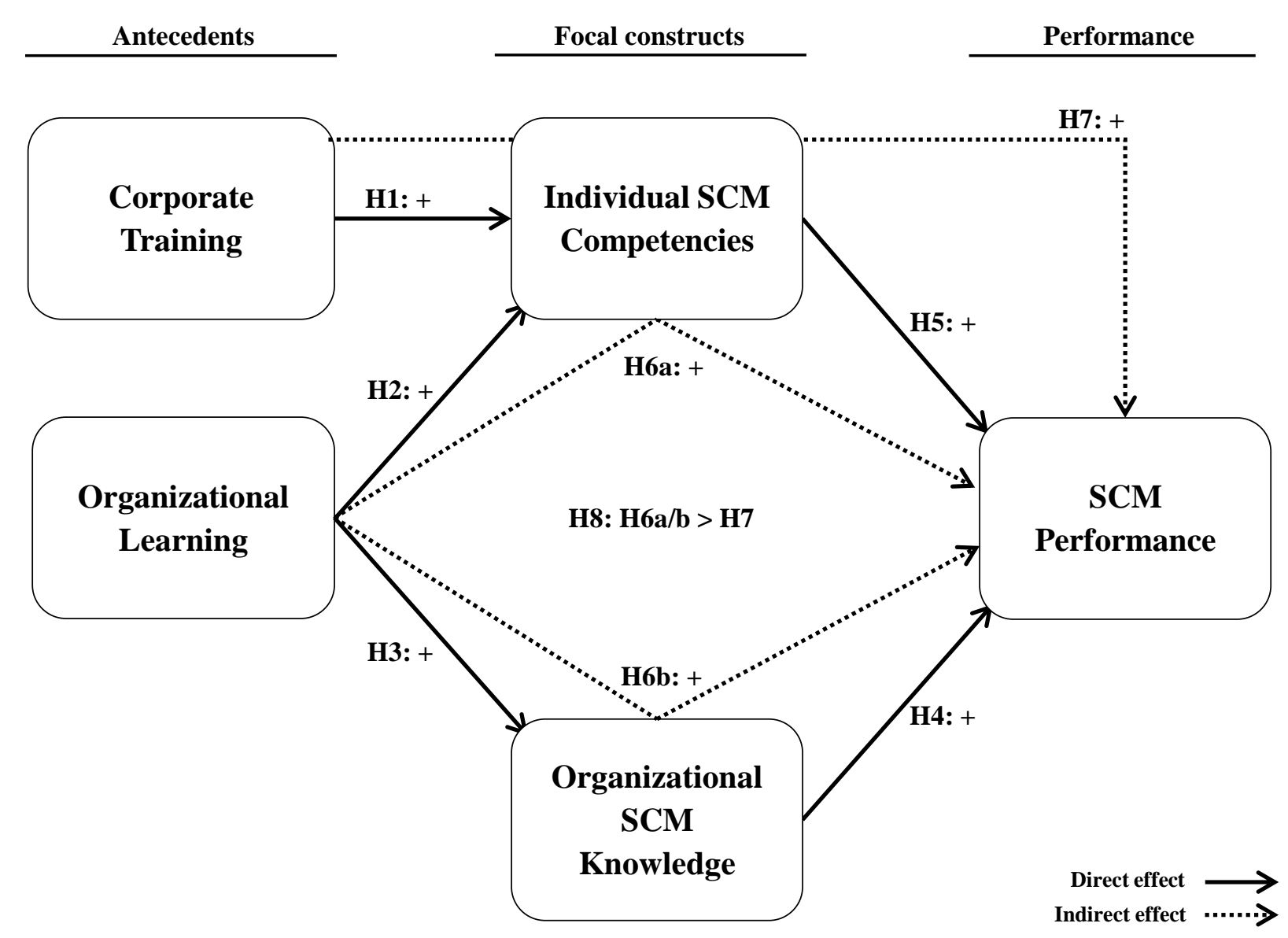




\section{Structural Model: direct effects - Figure 2}

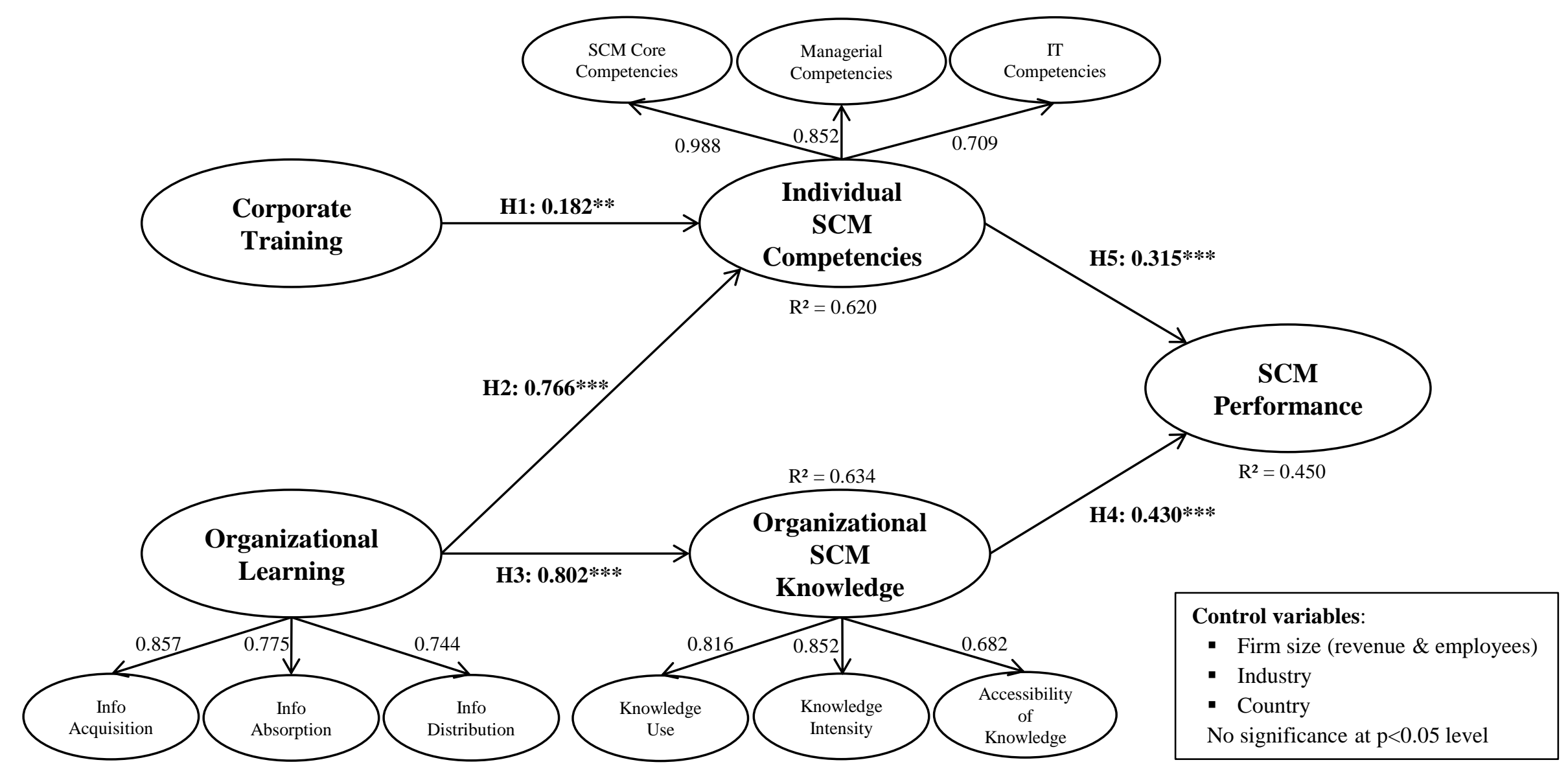




\section{TABLE 1: DESCRIPTIVE SAMPLE STATISTICS}

\begin{tabular}{|c|c|c|c|c|c|c|c|c|}
\hline$n=273$ & $\mathbf{n}$ & $\%$ & & $\mathbf{n}$ & $\%$ & & $\mathbf{n}$ & $\%$ \\
\hline Industry & & & \multicolumn{3}{|c|}{ Company revenue (in euros) } & \multicolumn{3}{|c|}{ Business experience (in years) } \\
\hline Automotive \& Parts & 34 & $12.5 \%$ & Below $10 \mathrm{mn}$ & 8 & $2.9 \%$ & Less than 2 & 12 & $4.4 \%$ \\
\hline Chemicals & 28 & $10.3 \%$ & $10-250 \mathrm{mn}$ & 39 & $14.3 \%$ & $2-5$ & 40 & $14.7 \%$ \\
\hline Construction \& Materials & 10 & $3.7 \%$ & $>250 \mathrm{mn}-1 \mathrm{bn}$ & 38 & $13.9 \%$ & $>5-10$ & 52 & $19.0 \%$ \\
\hline Food \& Beverages & 23 & $8.4 \%$ & $>1-10$ bn & 90 & $33.0 \%$ & $>10-25$ & 144 & $52.7 \%$ \\
\hline Healthcare & 36 & $13.2 \%$ & Above 10 bn & 98 & $35.9 \%$ & More than 25 & 25 & $9.2 \%$ \\
\hline $\begin{array}{l}\text { Industrial Goods \& } \\
\text { Services }\end{array}$ & 49 & $17.9 \%$ & \multicolumn{3}{|l|}{ Company employees } & \multicolumn{3}{|c|}{ Company experience (in years) } \\
\hline Oil \& Gas & 5 & $1.8 \%$ & $1-50$ & 7 & 2.6 & less than 2 & 46 & $16.8 \%$ \\
\hline $\begin{array}{l}\text { Personal and Household } \\
\text { Goods }\end{array}$ & 11 & $4.0 \%$ & $51-500$ & 27 & $9.9 \%$ & $2-5$ & 80 & $29.3 \%$ \\
\hline Retail & 26 & $9.5 \%$ & $501-1,000$ & 18 & $6.6 \%$ & $>5-10$ & 70 & $25.6 \%$ \\
\hline Technology & 32 & $11.7 \%$ & $1,001-10,000$ & 66 & $24.2 \%$ & $>10-25$ & 67 & $24.5 \%$ \\
\hline Telecommunication & 7 & $2.6 \%$ & more than 10,000 & 155 & $56.8 \%$ & More than 25 & 10 & $3.7 \%$ \\
\hline Utilities & 5 & $1.8 \%$ & \multirow{3}{*}{$\begin{array}{l}\text { Hierarchical level } \\
\text { Top management level } \\
\text { Middle management level }\end{array}$} & \multirow{3}{*}{$\begin{array}{c}23 \\
116\end{array}$} & \multirow{3}{*}{$\begin{array}{c}8.4 \% \\
42.5 \%\end{array}$} & \multicolumn{3}{|l|}{ Country } \\
\hline Others & 7 & $2.6 \%$ & & & & Austria & 13 & $4.8 \%$ \\
\hline Department & & & & & & Denmark & 50 & $18.3 \%$ \\
\hline SCM & 178 & $65.2 \%$ & Lower management level & 70 & $25.6 \%$ & Germany & 145 & $53.1 \%$ \\
\hline Logistics & 26 & $9.5 \%$ & No mgmt. responsibility & 64 & $23.4 \%$ & Switzerland & 22 & $8.1 \%$ \\
\hline Procurement/Sourcing & 31 & $11.4 \%$ & & & & Other & 43 & $15.8 \%$ \\
\hline Production/Manufacturing & 8 & $2.9 \%$ & & & & & & \\
\hline Other & 30 & $11.0 \%$ & & & & & & \\
\hline
\end{tabular}

TABLE 2: RESULTS OF CFA: CONVERGENT VALIDITY AND MEASUREMENT RELIABILITY

\begin{tabular}{|c|c|c|c|c|c|c|c|}
\hline$n=273$ & Mean & SD & CR & $\begin{array}{c}\text { Cronbach's } \\
\text { Alpha }\end{array}$ & AVE & MSV & ASV \\
\hline $\begin{array}{l}\text { Organizational Learning } \\
\text { Information distribution } \\
\text { Information acquisition } \\
\text { Information absorption }\end{array}$ & $\begin{array}{l}4.55 \\
4.13 \\
4.67 \\
4.87\end{array}$ & $\begin{array}{l}1.49 \\
1.55 \\
1.43 \\
1.40\end{array}$ & $\begin{array}{l}0.854 \\
0.886 \\
0.768 \\
0.788\end{array}$ & $\begin{array}{l}0.875 \\
0.746 \\
0.784\end{array}$ & 0.660 & 0.558 & 0.401 \\
\hline Corporate Training & 4.12 & 1.69 & 0.881 & 0.880 & 0.649 & 0.475 & 0.255 \\
\hline SCM Performance & 4.89 & 1.30 & 0.866 & 0.851 & 0.527 & 0.415 & 0.300 \\
\hline $\begin{array}{l}\text { Individual SCM Competencies } \\
\text { SCM core competencies } \\
\text { IT competencies } \\
\text { Managerial competencies }\end{array}$ & $\begin{array}{l}4.99 \\
4.88 \\
4.64 \\
5.45\end{array}$ & $\begin{array}{l}1.42 \\
1.39 \\
1.48 \\
1.25\end{array}$ & $\begin{array}{l}0.902 \\
0.792 \\
0.885 \\
0.805\end{array}$ & $\begin{array}{l}0.791 \\
0.882 \\
0.802 \\
\end{array}$ & 0.757 & 0.585 & 0.382 \\
\hline $\begin{array}{l}\text { Organizational SCM Knowledge } \\
\text { Knowledge access } \\
\text { Knowledge intensity } \\
\text { Knowledge use } \\
\end{array}$ & $\begin{array}{l}4.63 \\
4.31 \\
4.68 \\
4.89 \\
\end{array}$ & $\begin{array}{l}1.50 \\
1.60 \\
1.53 \\
1.30 \\
\end{array}$ & $\begin{array}{l}0.831 \\
0.861 \\
0.905 \\
0.894 \\
\end{array}$ & $\begin{array}{l}0.855 \\
0.901 \\
0.893 \\
\end{array}$ & 0.624 & 0.585 & 0.366 \\
\hline
\end{tabular}

All measures are on a Likert scale from 1 to 7

$\mathrm{CR}=$ Composite reliability, $\mathrm{AVE}=$ average variance extracted

Model fit: $\mathrm{CFI}=0.943, \mathrm{IFI}=0.943, \mathrm{TLI}=0.937, \mathrm{RMSEA}=0.047$ with $\mathrm{P}-\mathrm{CLOSE}=0.840$ 
TABLE 3: DISCRIMINANT VALIDITY: FACTOR CORRELATIONS WITH LOWER AND UPPER BOUNDS OF 95\% CONFIDENCE INTERVALS

\begin{tabular}{|l|c|c|c|c|c|}
\hline Constructs & OL & CT & IC & \\
\hline Organizational Learning (OL) & $\mathbf{0 . 8 1 2}$ & & & & \\
\hline Corporate Training (CT) & $\begin{array}{c}0.689 \\
0.547-0.791 \\
0.022\end{array}$ & $\mathbf{0 . 8 0 5}$ & & & \\
\hline SCM Performance (SCMP) & $\begin{array}{c}0.627 \\
0.516-0.721\end{array}$ & $\begin{array}{c}0.430 \\
0.316-0.555\end{array}$ & $\mathbf{0 . 7 2 6}$ & & \\
\hline Individual SCM Competencies (IC) & $\begin{array}{c}0.747 \\
0.636-0.853\end{array}$ & $\begin{array}{c}0.565 \\
0.46-0.661 \\
0.176\end{array}$ & $\begin{array}{c}0.616 \\
0.507-0.713\end{array}$ & $\mathbf{0 . 8 7 0}$ & \\
\hline Organizational SCM Knowledge (OK) & $\begin{array}{c}0.714 \\
0.592-0.832\end{array}$ & $\begin{array}{c}0.491 \\
0.348-0.654\end{array}$ & $\begin{array}{c}0.644 \\
0.529-0.746\end{array}$ & $\begin{array}{c}0.636-0.853 \\
0.035\end{array}$ & $\mathbf{0 . 7 9 0}$ \\
\hline
\end{tabular}

Square root of AVE on diagonal in bold All correlations significant at $\mathrm{p}<0.001$

Italics show p-values of the 3 failed adjusted $\chi^{2}$-difference tests; all others were below 0.005 (adjusted $5 \%$ significance level) and are not displayed in the table

TABLE 4: RESULTS OF SEM: HYPOTHESIS TESTING

\begin{tabular}{|l|c|c|c|c|}
\hline Direct relationships & Hypothesis & Support & \multicolumn{2}{c|}{$\begin{array}{c}\text { Standardized } \\
\text { regression weight } \\
\text { (SRW) }\end{array}$} \\
\hline Corp. Training $\rightarrow$ Ind. Competencies & H1 & Partial & 0.182 & $2.171^{* *}$ \\
\hline Org. Learning $\rightarrow$ Ind. Competencies & H2 & Full & 0.766 & $7.589 * * *$ \\
\hline Org. Learning $\rightarrow$ Org. Knowledge & H3 & Full & 0.802 & $7.069 * * *$ \\
\hline Org. Knowledge $\rightarrow$ SCM Performance & H4 & Full & 0.430 & $4.097^{* * *}$ \\
\hline Ind. Competencies $\rightarrow$ SCM Performance & H5 & Full & 0.315 & $3.421^{* * *}$ \\
\hline
\end{tabular}

${ }_{* * *} \mathrm{p}<0.001,{ }^{* *} \mathrm{p}<0.01,{ }^{*} \mathrm{p}<0.05$

Model fit: $\mathrm{CFI}=0.921, \mathrm{IFI}=0.922, \mathrm{TLI}=0.915, \mathrm{RMSEA}=0.054$ with $\mathrm{P}-\mathrm{CLOSE}=0.080$

Squared multiple correlations $\left(\mathrm{R}^{2}\right)$ for endogenous constructs: Ind. Competencies $=0.620$, Org. Knowledge $=0.634$, SCM Performance $=0.450$

$\mathrm{t}$-values from unstandardized solution 
TABLE 5: BOOTSTRAPPING MEDIATION ANALYSIS: INDIRECT EFFECTS

\begin{tabular}{|c|c|c|c|c|}
\hline Indirect relationships & Indirect SRW & \multicolumn{2}{|c|}{ Bootstrapped 95\% CI } & Hypotheses \\
\hline 20 & & $\begin{array}{l}\text { Lower } \\
\text { Bound }\end{array}$ & $\begin{array}{l}\text { Upper } \\
\text { Bound }\end{array}$ & \\
\hline \multicolumn{5}{|l|}{ Mediated by Individual Competencies } \\
\hline Corp. Training $\rightarrow$ SCM Performance & $0.057 * *$ & 0.012 & 0.133 & H7: Partially supported \\
\hline Org. Learning $\rightarrow$ SCM Performance & $0.241 * *$ & 0.077 & 0.440 & H6a: Supported \\
\hline \multicolumn{5}{|l|}{ Mediated by Organizational Knowledge } \\
\hline Org. Learning $\rightarrow$ SCM Performance & $0.344 * *$ & 0.139 & 0.561 & H6b: Supported \\
\hline \multicolumn{5}{|l|}{ Total Indirect Effects } \\
\hline Corp. Training $\rightarrow$ SCM Performance & $0.057 * *$ & 0.012 & 0.133 & \multirow{2}{*}{ H8: H6a/b > H7: Supported } \\
\hline Org. Learning $\rightarrow$ SCM Performance & $0.586^{* * *}$ & 0.474 & 0.685 & \\
\hline
\end{tabular}

$* * * \mathrm{p}<0.001, * * \mathrm{p}<0.01, * \mathrm{p}<0.05$

Indirect SRW and bounds estimated by bootstrapping 5,000 random samples with the bias-corrected percentile method $(95 \%$ confidence interval) 